\title{
Current Trends of Plants Having Antidiabetic Activity: A Review
}

\section{Saminathan Kayarohanam ${ }^{1 *}$ and S Kavimani ${ }^{2}$}

${ }^{1}$ Jawaharlal Nehru Technological University Hyderabad, Andhra Pradesh, India

${ }^{2}$ Mother Theresa Institute of Health Sciences, Puducherry, India

\begin{abstract}
Medicinal plants have been proposed as rich yet unexploited potential sources for antidiabetic drugs, even though used since ancient times for the treatment of diabetes mellitus. Many of the synthetic drugs were discovered either directly or indirectly from the plant source. The present study reviews of plants having antidiabetic property. Although many plants are recommendation, further pharmacological and chemical research should be done to elucidate the exact mechanism of hypoglycemic activity.
\end{abstract}

Keywords: Diabetes mellitus; Medicinal plants; Antidiabetic; Alloxan; Streptozotocin

\section{Introduction}

Diabetes mellitus is a metabolic disorder, characterized by chronic hyperglycemia, with disturbances of carbohydrate, fat and protein metabolism, resulting defects in insulin secretion, insulin action, or both [1]. More than 347 million people are affected by diabetes worldwide [2]. The prevalence of diabetes has risen from $2.4 \%$ to $6.4 \%$ in the last 15 years [3]. Diabetes related deaths are more common in the low and middle-income countries where more than $80 \%$ deaths occur [4].The World Health Organization projects that diabetes will be the $7^{\text {th }}$ leading cause of death in 2030 [5].

Traditional, complementary and alternative medicines have been used since ancient times. Yet the use of traditional medicine (TM) remains widespread in developing countries, while use of complementary and alternative medicine (CAM) is increasing rapidly in developed countries. In many parts of the world, policy-makers, health professionals and the public are wrestling with questions about the safety, efficacy, quality, availability, preservation and further development of this type of health care. TM is sometimes also the only affordable source of health care especially for the world's poorest patients [6].

Indian traditional health care system uses a number of medicinal plants traditionally over 1000 years in herbal preparations. Medicinal plants, minerals and organic matter cover a major part of traditional medicines. Most of the Indian traditional medical practitioners formulate and dispense their own recipes. 21,000 plants are listed by the WHO, which are used for medicinal purposes around the world. Among these, 2500 species are in India, out of which, 150 species are used commercially on a fairly large scale. India is the largest producer of medicinal herbs and is called the botanical garden of the world [7-11]. Ethnobotanical information reports about 800 plants which possess anti-diabetic potential [12].

TM/CAM is used to treat 200 million patients annually. WHO Regional office reports that $71 \%$ of the population in Chile and $40 \%$ of the population in Colombia are using TM. Many developed countries uses CAM 46\% in Australia, 49\% in France and 70\% in Canada [13-17]. Even though plant sources are potential antidiabetic drugs, they have not gained sufficient momentum among the scientific community. The present study reviews the medicinal plants used for antidiabetic activity.

\section{Materials and Methods}

A current review was done by selecting 50 research papers with antidiabetic effect from plant sources (Table 1).

\section{Results}

Investigations of medicinal plants with different species and families were studied. Different parts of the plants were used for the antidiabetic study. The methanol, ethanol and aqueous solvents were most commonly used for the extractions. The preliminary phytochemical analyses mostly show the presence of terpenoids and flavonoids. Efficacy evaluation of medicinal plants was done by streptozotozine or alloxone induced diabetic modules. Most of the research results showed the hypoglycaemic effects and almost the same effect of standard drugs. Numerous mechanisms of action had been proposed for the plant extracts.

\section{Discussion}

Diabetes is a chronic disease that occurs when the body cannot produce enough insulin or cannot use insulin effectively [69]. It is projected that 300 million people will have the disease by the year 2025 [70] and it may reach to 366 million in the year 2030 [71]. Type 2 diabetes is a common condition and a serious global health problem. In most countries, diabetes has increased alongside rapid cultural and social changes: ageing populations, increasing urbanisation, dietary changes, reduced physical activity and unhealthy behaviours [72]. A person's risk of developing Type 2 Diabetes Mellitus has been shown to be highly linked to obesity and any family history of diabetes [73]. Hyperglycaemic condition causes increased glycosylation leading to biochemical and morphological abnormalities due to altered protein structure and develop the neuropathy, retinopathy, neuropathy and cardiomyopathy [74]. Diabetes kills 1.1 million people in 2005 and more than 220 million people worldwide have diabetes, almost $80 \%$ of

${ }^{*}$ Corresponding author: Kayarohanam S, 79/85-B Viswas Nagar, 3rd Cross Street, Karumandapam, Trichy-620001, Tamil Nadu, India, Tel: +919025409990; E-mail: samiveni@gmail.com

Received February 25, 2015; Accepted April 06, 2015; Published April 10, 2015

Citation: Kayarohanam S, Kavimani S (2015) Current Trends of Plants Having Antidiabetic Activity: A Review. J Bioanal Biomed 7: 055-065. doi:10.4172/1948593X.1000124

Copyright: (c) 2015 Kayarohanam S, et al. This is an open-access article distributed under the terms of the Creative Commons Attribution License, which permits unrestricted use, distribution, and reproduction in any medium, provided the original author and source are credited. 
Citation: Kayarohanam S, Kavimani S (2015) Current Trends of Plants Having Antidiabetic Activity: A Review. J Bioanal Biomed 7: 055-065. doi:10.4172/1948-593X.1000124

\begin{tabular}{|c|c|c|c|c|c|c|c|}
\hline & $\begin{array}{l}\text { Scientific Name/ } \\
\text { (Family) }\end{array}$ & Parts Used & Extraction & $\begin{array}{l}\text { Diabetic induced by/ } \\
\text { Efficacy Evaluation }\end{array}$ & Active Ingredient & $\begin{array}{l}\text { Probable Mechanism } \\
\text { of action }\end{array}$ & References \\
\hline 1 & $\begin{array}{l}\text { Acanthopanax } \\
\text { senticosus } \\
\text { (Araliaceae) }\end{array}$ & Whole plant & Aqueous & $\begin{array}{l}\text { Alloxan/polysaccharides of this plant } \\
\text { decreased the blood glucose, blood lipid } \\
\text { (TC and TG), TBARS, GSH, ALT AST, } \\
\text { ALP, creatinine, total bilirubin, and urea } \\
\text { levels, at the same time it also increased } \\
\text { the body weight, liver glycogen formation, } \\
\text { and antioxidant enzyme (SOD and GPX) } \\
\text { levels as compared with those of diabetic } \\
\text { control group. }\end{array}$ & Polysaccharide. & $\begin{array}{l}\text { Potent antioxidant } \\
\text { activity leads to } \\
\text { antidiabetic activity. }\end{array}$ & [18] \\
\hline 2 & $\begin{array}{l}\text { Acorus calamus } \\
\text { (Acoraceae) }\end{array}$ & Rhizome & Methanol & $\begin{array}{l}\text { Streptozotocin/The crude extract reduced } \\
\text { the fasting blood glucose significantly and } \\
\text { produce the maximum improvement in } \\
\text { glucose tolerance and increase the serum } \\
\text { insulin levels. }\end{array}$ & $\begin{array}{l}\text { Phenylpropanoids, } \\
\text { sesquiterpenes, } \\
\text { monoterpenes, } \\
\text { xanthone glycosides, } \\
\text { flavones, steroids, } \\
\text { lignans, } \\
\text { triterpenoidand } \\
\text { saponins. }\end{array}$ & $\begin{array}{l}\text { Decrease the activity of } \\
\text { glucose }-6 \text { phosphates } \\
\text { and fructose } 1,6 \\
\text { phosphatase enzymes. }\end{array}$ & [19] \\
\hline 3 & $\begin{array}{l}\text { Adina cordifolia } \\
\text { (Rubiaceae) }\end{array}$ & Leaves & Hydro-alcoholic & $\begin{array}{l}\text { Alloxan/In this study, the extract } \\
\text { given to diabetic rats continuously for } 15 \\
\text { days, It will produce the dose-dependent } \\
\text { reduction of blood glucose level compared } \\
\text { to diabetic control rats. }\end{array}$ & $\begin{array}{l}\text { Tannins, saponins } \\
\text { and flavonoids. }\end{array}$ & $\begin{array}{l}\text { Increase the insulin } \\
\text { secretion or inhibit the } \\
\text { intestinal absorption of } \\
\text { glucose. }\end{array}$ & [20] \\
\hline 4 & $\begin{array}{l}\text { Cocos nucifera } \\
\text { (Arecaceae) }\end{array}$ & Spadix & Hydro-methanol & $\begin{array}{l}\text { Streptozotocin/Significant reduction in } \\
\text { fasting blood glucose level as compared } \\
\text { with diabetic control group. Serum } \\
\text { enzyme level (SGOT, SGPT, SALP), lipid } \\
\text { peroxidation and antioxidant enzyme level } \\
\text { such as CAT, GSH, SOD and cholesterol } \\
\text { and triglycerides in the Cocos nucifera } \\
\text { treated groups were restored towards } \\
\text { normal level as compared to diabetic control } \\
\text { groups and the values were comparable } \\
\text { with the standard } \\
\text { groups (glibenclamide). }\end{array}$ & $\begin{array}{l}\text { Flavonoid, tannin and } \\
\text { saponin. }\end{array}$ & $\begin{array}{l}\text { Potentiating the insulin } \\
\text { effect of plasma by } \\
\text { increasing either the } \\
\text { pancreatic secretion of } \\
\text { insulin from the existing } \\
\beta \text { cells or by its release } \\
\text { from the bound insulin. }\end{array}$ & [21] \\
\hline 5 & $\begin{array}{l}\text { Afzelia africana } \\
\text { (Fabaceae) }\end{array}$ & Stem Bark & Aqueous & $\begin{array}{l}\text { Streptozotocin/Blood glucose level was } \\
\text { significantly reduced }(P<0.05) \text {. After the plant } \\
\text { extract administration the feed and water } \\
\text { intake was markedly reduced as compared } \\
\text { with the diabetic untreated rats. }\end{array}$ & $\begin{array}{l}\text { Flavonoids, } \\
\text { proanthocyanidins, } \\
\text { tannins, phenols and } \\
\text { flavonols. }\end{array}$ & $\begin{array}{l}\text { Potentiating of insulin } \\
\text { from } \beta \text { cells or by } \\
\text { increasing peripheral } \\
\text { glucose uptake. }\end{array}$ & [22] \\
\hline 6 & & Leaves & Alcoholic & $\begin{array}{l}\text { Streptozotocin-Nicotinamide/Significant } \\
\text { reduction of TG, TC, LDL and increase } \\
\text { in HDL level was observed after the } \\
\text { administration of plant extract. Significantly } \\
\text { increased the SOD and CAT and reduced } \\
\text { the TBARS level and conclude that the } \\
\text { alcohol leaf extract increase the utilization } \\
\text { of glucose uptake increased as similar as } \\
\text { biguanides. }\end{array}$ & $\begin{array}{l}\text { Alkaloid, } \\
\text { terpenoids, } \\
\text { steroids, } \\
\text { tannins and phenol. }\end{array}$ & $\begin{array}{l}\text { Improvement in glucose } \\
\text { tolerance, restoration } \\
\text { of liver glycogen and } \\
\text { antioxidant activity } \\
\text { to reduce the risk of } \\
\text { secondary complication } \\
\text { associated with } \\
\text { diabetes. }\end{array}$ & [23] \\
\hline 7 & & Bark & Methanol & $\begin{array}{l}\text { Alloxan/The bark extract significantly } \\
\text { reduced the blood sugar level and reduced } \\
\text { the serum cholesterol, triglycerides, serum } \\
\text { glutamic-oxaloacetic transaminase, serum } \\
\text { glutamine-pyruvic transaminase and } \\
\text { alkaline phosphate. }\end{array}$ & $\begin{array}{l}\text { Bi flavonoids, } \\
\text { triterpene glycosides, } \\
\text { saponins, sapogenins } \\
\text { and fatty acids. }\end{array}$ & $\begin{array}{l}\text { Insulin secretion } \\
\text { and improvement of } \\
\text { glycogenesis process. }\end{array}$ & [24] \\
\hline 8 & & Leaves & Methanol & $\begin{array}{l}\text { Streptozotocin/All the three plants showed } \\
\text { significant anti-diabetic activity and } \\
\text { anticholesteremic activity. }\end{array}$ & Flavonoids. & $\begin{array}{l}\text { Protect the loss of } \\
\text { degradation of structural } \\
\text { proteins (which is } \\
\text { contributed to the body } \\
\text { weight). Presence } \\
20 \% \text { proteins and } 8 \\
\text { essential aminoacids } \\
\text { (lysine,threonind and } \\
\text { tryptophan), vitamins, } \\
\text { calcium and minerals in } \\
\text { the plant extract reduce } \\
\text { the hyperglycemia. }\end{array}$ & [25] \\
\hline 9 & & Stem & Methanol & $\begin{array}{l}\text { Streptozotocin/The plant estract significantly } \\
\text { reduce the blood glucose level in dose } \\
\text { dependent manner and modulated the lipid } \\
\text { profile changes in STZ diabetic rates in a } \\
\text { dose dependent manner. }\end{array}$ & $\begin{array}{l}\text { Terpenoids, } \\
\text { steroids, } \\
\text { phenolic compounds, } \\
\text { flavonoids } \\
\text { and aminoacid. }\end{array}$ & $\begin{array}{l}\text { Decrease the glycated } \\
\text { haemoglobin levels and } \\
\text { improvement in insulin } \\
\text { secretion. }\end{array}$ & [26] \\
\hline
\end{tabular}


Citation: Kayarohanam S, Kavimani S (2015) Current Trends of Plants Having Antidiabetic Activity: A Review. J Bioanal Biomed 7: 055-065. doi:10.4172/1948-593X.1000124

\begin{tabular}{|c|c|c|c|c|c|c|}
\hline 10 & bark & aqueous & $\begin{array}{l}\text { Streptozotocin/In this study the bark extract } \\
\text { increase the body weight, hemoglobin and } \\
\text { decreased blood glucose level. }\end{array}$ & $\begin{array}{l}\text { Flavonoid, tannins, } \\
\text { and ellagic acid. }\end{array}$ & $\begin{array}{l}\text { Reversal of insulin } \\
\text { resistant by increasing } \\
\text { insulin secretion. }\end{array}$ & [27] \\
\hline 11 & $\begin{array}{l}\text { Leaves } \\
\text { Stem Bark } \\
\text { root }\end{array}$ & Methanol & $\begin{array}{l}\text { Alloxan/The leaves and stem bark } \\
\text { crude methanol extracts of } \text { Anthocleista } \\
\text { djalonensis gave comparable alpha } \\
\text { amylase inhibition of } 73.66 \% \text { and } 72.90 \% \text {, } \\
\text { respectively which were quite higher than } \\
\text { the } 38.93 \% \text { and } 22.90 \% \text { of the same plant } \\
\text { parts given by Anthocleista vogelii. The } \\
\text { crude stem bark extract of Anthocleista } \\
\text { djalonensis exhibited significant peak } \\
\text { blood glucose reduction on day } 6(72.59 \% \text {, } \\
\text { p<0.05) which was higher than the leaves } \\
\text { or roots which gave } 45.73 \% \text { and } 47.46 \% \\
\text { (p<0.05), respectively the stem bark ethyl } \\
\text { acetate fraction of Anthocleista djalonensis } \\
\text { gave reduction in blood glucose level of } \\
60.86 \%(p<0.05) \text {. }\end{array}$ & - & $\begin{array}{l}\text { Alpha Amylase inhibitory } \\
\text { activity. }\end{array}$ & [28] \\
\hline 12 & Root & Ethanol & $\begin{array}{l}\text { Alloxan/The extract fraction casused a } \\
\text { significant }(P<0.001) \text { reduction in fasting } \\
\text { blood glucose of the diabetic rats both in } \\
\text { acute and study and prolonged study ( } 2 \\
\text { weeks). The overall activities of the plant } \\
\text { extraction were more than that of the } \\
\text { reference drug, Glibenclamide. }\end{array}$ & $\begin{array}{l}\text { Alkaloids, } \\
\text { flavonoids, tannins, } \\
\text { terpenes, saponins, } \\
\text { anthraquinones, } \\
\text { reducing sugar and } \\
\text { cardio glycoside. }\end{array}$ & $\begin{array}{l}\text { Potentiating the } \\
\text { insulin effect by } \\
\text { increasing the pancreatic } \\
\text { secretion } \\
\text { of insulin from the cells } \\
\text { of islets of langerhans. }\end{array}$ & [29] \\
\hline 13 & Leaf & Methanol & $\begin{array}{l}\text { Alloxan/Leaf extract compresses at all } \\
\text { the doses }(250,500 \text { and } 1000 \mathrm{mg} / \mathrm{kg}) \\
\text { used caused a respective time dependent } \\
\text { and significant }(\mathrm{p}<0.0001) \text { reduction (by } \\
31.5 \%, 19.8 \% \text { and } 24.5 \%) \text { of the blood } \\
\text { glucose levels in the diabetic rats when } \\
\text { compared to the negative control group } \\
\text { at the } 6^{\text {th }} \text { hour. However, the reference } \\
\text { drug (glibenclamide, } 2 \mathrm{mg} / \mathrm{kg}) \text { decreased } \\
\text { the blood glucose levels by } 69.9 \% \text { and } \\
\text { the tween } 20 \text { solution (negative control) } \\
\text { increased the blood glucose level by } 15.2 \% \\
\text { at the } 6^{\text {th }} \text { hour. }\end{array}$ & $\begin{array}{l}\text { Glycoside, } \\
\text { flavonoids and } \\
\text { tannins. }\end{array}$ & $\begin{array}{l}\text { Stimulation of surviving } \\
\beta \text { cells to release } \\
\text { more insulin just like } \\
\text { glibenclamide. }\end{array}$ & [30] \\
\hline 14 & stembark & Ethanol & $\begin{array}{l}\text { Streptozotocin/The plant extract significantly } \\
\text { reduced the blood sugar at doe level } 353 \\
\mathrm{mg} / \mathrm{kg} \text { from } 2 \text { to } 24 \text { hours while compared to } \\
\text { glibenclamide }(5 \mathrm{mg} / \mathrm{Kg})\end{array}$ & $\begin{array}{l}\text { Alkaloids, flavonoids, } \\
\text { steroids, glycosides, } \\
\text { saponins, tannins and } \\
\text { terpenoids. }\end{array}$ & $\begin{array}{l}\text { Increases the level of } \\
\text { insulin secretion. }\end{array}$ & [31] \\
\hline 15 & Stem bark & Ethanol & $\begin{array}{l}\text { Alloxan/Steam bark extract exhibit } \\
\text { significant hypoglycemic activity at different } \\
\text { doses and intervals and } 22.2 \% \text { more potent } \\
\text { than the standard oral hypoglycemic drug } \\
\text { glibenclamide } 0.2 \mathrm{mg} / \mathrm{kg} \text {. }\end{array}$ & $\begin{array}{l}\text { Flavonoids, } \\
\text { Tannins, } \\
\text { alkaloids, } \\
\text { cardio glycoside, } \\
\text { anthraquinones, } \\
\text { saponines and } \\
\text { triterpenes. }\end{array}$ & $\begin{array}{l}\text { The mode of action } \\
\text { like glinenclamide and } \\
\text { extra pancreatic effects. } \\
\text { Pytochemical screening } \\
\text { showed the presence } \\
\text { of cardiac glycosides, } \\
\text { flavonoids, saponins and } \\
\text { tannins in the extracts } \\
\text { and the many researched } \\
\text { documented the } \\
\text { hypoglycemic properties } \\
\text { of falvonoids may be the } \\
\text { reason for antdiabetic } \\
\text { properties. }\end{array}$ & [32] \\
\hline 16 & seeds & $\begin{array}{l}\text { Ethanol/ } \\
\text { Butanol }\end{array}$ & $\begin{array}{l}\text { Streptozotocin/Administration of both extract } \\
\text { significantly }(\mathrm{P}<0.5) \text { lower the fasting blood } \\
\text { glucose leve in daiabetic rats by } 55 \% \text {, } \\
64 \% \text {, and } 56 \% \text {. Similarly serum superoxide } \\
\text { dismutase activity was significantly }(\mathrm{P}<0.5) \\
\text { enhanced by treating the both extract. At } \\
\text { the same time both the extract significantly } \\
\text { decresed the elevated serum creatinine, urea, } \\
\text { total cholesterol, triglyceride and thiobarbituric } \\
\text { acid reactive species (TBARS) products in } \\
\text { diabetic rats. }\end{array}$ & $\begin{array}{l}\text { Cardioglycoside, } \\
\text { saponines, } \\
\text { alkaloids, } \\
\text { anthraquinones, } \\
\text { flavones, glycosides } \\
\text { and } \\
\text { tannins. }\end{array}$ & $\begin{array}{l}\text { By stimulation of few } \\
\text { surviving } \beta \text { cell to } \\
\text { release more insulin. }\end{array}$ & [33] \\
\hline 17 & root & Alcohol & $\begin{array}{l}\text { Streptozotocin/The dose dependent reduction } \\
\text { in fasting blood glucose level and glucose } \\
\text { tolerance test showed better tolerance of } \\
\text { glucose in treated rats. Decrease in lipid } \\
\text { peroxides and increase in superoxide } \\
\text { dismutase and catalase. Significant reduction in } \\
\text { triglycerides, total cholesterol and high density } \\
\text { lipo-protein cholesterol. }\end{array}$ & $\begin{array}{l}\text { Tannins } \\
\text { phenolics and } \\
\text { triterpinoids. }\end{array}$ & $\begin{array}{l}\text { Over production and } \\
\text { decreased utilisation of } \\
\text { the tissues. }\end{array}$ & [34] \\
\hline
\end{tabular}


Citation: Kayarohanam S, Kavimani S (2015) Current Trends of Plants Having Antidiabetic Activity: A Review. J Bioanal Biomed 7: 055-065. doi:10.4172/1948-593X.1000124

\begin{tabular}{|c|c|c|c|c|c|c|}
\hline 18 & leaves & Isolation flavones & $\begin{array}{l}\text { Streptozotocin/Significant blood glucose } \\
\text { lowering effects and compared to standard } \\
\text { glibenclamide. }\end{array}$ & Flavonoids & $\begin{array}{l}\text { Blood glucose lowering } \\
\text { by the regeneration of } \\
\text { pancreatic islets and } \\
\text { probably insulin release. }\end{array}$ & [35] \\
\hline 19 & leaves & Aqueous infusion & $\begin{array}{l}\text { Streptozotocin/Exhibited significant } \\
(P<0.05) \text {, dose-dependent and marked } \\
\text { hypoglycaemic and antihyperglycaemic } \\
\text { activities with quick onset. These effects } \\
\text { did not differ with respect to agroclimatic } \\
\text { elevation, although there were differences } \\
\text { in the content of phyto-constituents. }\end{array}$ & $\begin{array}{l}\text { Poly phenols, } \\
\text { caffeine, } \\
\text { theaflavins and } \\
\text { thearubigins. }\end{array}$ & $\begin{array}{l}\text { Inhibited intestinal } \\
\text { glucose absorption and } \\
\text { impaired a-glucosidase } \\
\text { and } \\
\alpha \text {-amylase activities. } \\
\text { Increasing the Insulin/ } \\
\text { glucose ratio. }\end{array}$ & [36] \\
\hline 20 & Fruits & Methanol & $\begin{array}{l}\text { Alloxan/Significantly lowered the elevated } \\
\text { blood glucose levels by } 48 \%(p<0.001) \text { and } \\
64.5 \%(p<0.001) \\
\text { respectively at dose level of } 400 \mathrm{mg} / \mathrm{kg} \\
\text { per oral after } 24 \mathrm{~h} \text { as compared to diabetic } \\
\text { control. } \\
\text { The polyphenolic and flavonoid content } \\
\text { of methanol extract and its ethyl acetate } \\
\text { soluble fraction were found to be } 15.8 \pm \\
1.2 \mathrm{mg} \text { and } 18.55 \pm 0.34 \mathrm{mg} \text { (gallic acid } \\
\text { equivalent/g extract) and } \\
\text { flavonoid content } 2.92 \pm 0.03 \mathrm{mg} \text { and } \\
1.534 \pm 0.30 \mathrm{mg} \text { (rutin equivalent/g extract) } \\
\text { respectively. }\end{array}$ & $\begin{array}{l}\text { Polyphenolic, } \\
\text { flavonoid and } \\
\text { flavanone. }\end{array}$ & $\begin{array}{l}\text { Increase in degree of } \\
\text { polymerization } \\
\text { and segregation of } \\
\text { secondary metabolites. }\end{array}$ & [37] \\
\hline 21 & Polysaochanides & $\begin{array}{l}\text { Isolation } \\
\text { Polysacchanides }\end{array}$ & $\begin{array}{l}\text { Streptozotocin/Significant decrease in } \\
\text { the concentrations of blood glucose, total } \\
\text { cholesterol (TC), triglycerides (TGs), low- } \\
\text { density lipoprotein-cholesterol (LDL-C) } \\
\text { and maleic dialdehyde (MDA). Significant } \\
\text { increase in the concentrations of high density } \\
\text { lipoprotein-cholesterol (HDL-C) and the } \\
\text { activities of antioxidant enzymes. }\end{array}$ & Polysaccharides. & $\begin{array}{l}\text { Polysaccharides may } \\
\text { stimulate pancreatic } \\
\text { release of insulin and/ } \\
\text { or reduce insulin } \\
\text { metabolism. }\end{array}$ & [38] \\
\hline 22 & fruits & Methanol & $\begin{array}{l}\text { Streptozotocin/The extract treat to the } \\
\text { diabetic rats were the doses of } 50 \text { and } \\
100 \mathrm{mg} / \mathrm{kg} \text { bw for } 14 \text { days. BG, TC, } \\
\text { TG, HDL-C, ALT, AST and AChE levels } \\
\text { were significantly reduced at the same } \\
\text { time antioxidant levels were significantly } \\
\text { increased in the treated groups. }\end{array}$ & $\begin{array}{l}\text { Bioactive } \\
\text { triterpenes } \\
\text { such as oleanolic } \\
\text { acid and ursolic acid. } \\
\text { Bioactive phenolic } \\
\text { acids } \\
\text { vitamin and } \\
\text { flavonoids. }\end{array}$ & $\begin{array}{l}\text { Inhibition } \\
\text { of glucose transporter, } \\
\text { a-glycosidase, } \\
\alpha \text {-amylase, lipase } \\
\text { and strong antioxidant } \\
\text { potential. }\end{array}$ & [39] \\
\hline 23 & Aerial part & Ethanol & $\begin{array}{l}\text { Cell Culture/The extract increased } \\
\text { insulin secretion in } \beta \text { cells as well as } \\
\text { glucose uptake in adipocytes and skeletal } \\
\text { myotubes. It also displayed hypoglycemic } \\
\text { activity in the diabetic sand rat. }\end{array}$ & Flavonoids. & $\begin{array}{l}\text { Reduction in hepatic } \\
\text { lipids is associated } \\
\text { with the decrease in } \\
\text { glucose absorption or } \\
\text { due to an independent } \\
\text { mechanism. }\end{array}$ & [40] \\
\hline 24 & leaves & Aqueous & $\begin{array}{l}\text { Streptozotocin/Blood glucose levels } \\
\text { decreased by ethanol extract at of } 250 \text { and } \\
500 \mathrm{mg} / \mathrm{kg} \text { doses as compared to control } \\
\text { group }(16 \%-34 \%) \text {. } \\
\text { It has the potent inhibitor of a-glucosidase } \\
\text { and a-amylase, possibly due to several } \\
\text { polyphenolic compounds present within the } \\
\text { extract. }\end{array}$ & $\begin{array}{l}\text { Tannins (ellagic } \\
\text { acid), sterols, } \\
\text { phenolic acids, } \\
\text { lignan glycosides, } \\
\text { phenolic compounds } \\
\text { and } \\
\text { flavonoids } \\
\text { (apigenin, quercetin } \\
\text { and kaempferol). }\end{array}$ & $\begin{array}{l}\text { Potent } \\
\text { inhibitor of } \alpha \\
\text {-glucosidase and } \\
\alpha \text {-amylase. }\end{array}$ & [41] \\
\hline 25 & barks & Methanol & $\begin{array}{l}\text { Streptozotocin/While compared to the } \\
\text { standard glibenclamide it shows the } \\
\text { significant decrease in blood glucose and } \\
\text { significant increase in plasma insulin and } \\
\text { liver glycogen levels in treated diabetic rats. } \\
\text { Further antilipidemic activity as evidenced } \\
\text { by significant decrease in serum TC, TG, } \\
\text { LDL-C levels and significant increase in } \\
\text { HDL-C level in treated diabetic rats. SCBe } \\
\text { also restored the altered plasma enzymes } \\
\text { (SGOT,SGPT and ALP), total protein, urea } \\
\text { and creatinine levels to near normal. }\end{array}$ & $\begin{array}{l}\text { Steroids, } \\
\text { Triterpenoids and } \\
\text { phenolic compounds. }\end{array}$ & $\begin{array}{l}\text { Potentiation } \\
\text { of the pancreatic } \\
\text { secretion of insulin from } \\
\text { regenerated } \\
\beta \text {-cells, or its action to } \\
\text { release bound insulin } \\
\text { from regenerated } \beta \text { cells } \\
\text { by inhibiting the ATP } \\
\text { sensitive K+ channels } \\
\text { like glibenclamide. }\end{array}$ & [42] \\
\hline
\end{tabular}


Citation: Kayarohanam S, Kavimani S (2015) Current Trends of Plants Having Antidiabetic Activity: A Review. J Bioanal Biomed 7: 055-065. doi:10.4172/1948-593X.1000124

\begin{tabular}{|c|c|c|c|c|c|c|}
\hline 26 & gum resin & Ethanol & $\begin{array}{l}\text { Streptozotocin/At the end of experimental } \\
\text { period of } 60 \text { days, showed an increase in } \\
\text { body weight. } \\
\text { A significant antihyperglycemic effect } \\
\text { was evident from } 15 \text { days onwards and the } \\
\text { decrease in plasma glucose was } 76.22 \% \\
\text { and significant increase in insulin level. } \\
\text { Showed a significant decrease in plasma total } \\
\text { cholesterol (20.73\%), triglycerides }(19.76 \%), \\
\text { LDL-cholesterol (41.66\%), VLDL cholesterol } \\
(22.22 \%) \text { and atherogenic index (33.32\%) } \\
\text { and a significant increase in HDL-cholesterol } \\
(14.81 \%) \text {. }\end{array}$ & $\begin{array}{l}\text { Sterols, sugars } \\
\text { (sucrose, fructose), } \\
\text { aminoacids, } \\
\text { camphorene, } \\
\text { Cembrene, } \\
\text { allylcembrol, resin, oil } \\
\text { and several steroids. }\end{array}$ & $\begin{array}{l}\text { Improvement in insulin } \\
\text { levels. }\end{array}$ & [43] \\
\hline 27 & fruit & Aqueous & $\begin{array}{l}\text { Streptozotocin/Significant increase in the } \\
\text { body weight, liver glycogen and } \\
\text { serum insulin level and decrease in the } \\
\text { blood glucose, glycosylated hemoglobin } \\
\text { levels, total cholesterol } \\
\text { and serum triglycerides. HDL cholesterol } \\
\text { level was significantly increased when } \\
\text { treated with the extract. }\end{array}$ & $\begin{array}{l}\text { Carbohydrates, } \\
\text { proteins and amino } \\
\text { acids. }\end{array}$ & $\begin{array}{l}\text { Increasing the pancreatic } \\
\text { secretion of insulin from } \\
\text { the existing } \beta \text {-cells. }\end{array}$ & [44] \\
\hline 28 & root & Methanol & $\begin{array}{l}\text { Alloxan/Significantly reduced the } \\
\text { blood glucose, serum total cholesterol, } \\
\text { triglyceride, AST and ALT levels. At the } \\
\text { same time increased liver glycogen content. } \\
\text { OGTT was performed by administration of } \\
200 \mathrm{mg} \text { and } \\
400 \mathrm{mg} \text { and } 7 \mathrm{mg} \text { of glibenclamide to } \\
\text { different groups respectively which } \\
\text { significantly lower at all time points that } \\
\text { blood was sampled after oral } \\
\text { glucose load. }\end{array}$ & $\begin{array}{l}\text { Flavanoids, } \\
\text { sterols, triterpenoids, } \\
\text { alkaloids and } \\
\text { phenolics. }\end{array}$ & $\begin{array}{l}\text { Promote insulin } \\
\text { secretion by } \\
\text { closure of } \mathrm{K}^{+}-\mathrm{ATP} \\
\text { channels, membrane } \\
\text { depolarization and } \\
\text { stimulation } \\
\text { of calcium influx, an } \\
\text { initial key step in insulin } \\
\text { secretion. }\end{array}$ & [45] \\
\hline 29 & Leaves & Methanol & $\begin{array}{l}\text { Alloxan/Oral administration of the extract } \\
\text { ( } 250 \text { and } 500 \mathrm{mg} / \mathrm{kg} \text { body weight) produce } \\
\text { beneficial effects of blood glucose level } \\
(\mathrm{P}<0.001) \text { while compare the drug } \\
\text { (glibenclamide } 10 \mathrm{mg} / \mathrm{kg} \text { ). Enhance the } \\
\text { serum insulin level and body weight and } \\
\text { there are no histopathological changes. }\end{array}$ & Poly phenols. & $\begin{array}{l}\text { Stimulation of insulin } \\
\text { secretion. }\end{array}$ & [46] \\
\hline 30 & Berries & Methanol & $\begin{array}{l}\text { Alloxan/Significantly increase in } \\
\text { bodyweight, reduced the elevated plasma } \\
\text { glucose, glycosylated haemoglobin and pro- } \\
\text { inflammatory mediators (interleukin } 6 \text { and } \\
\text { tumour necrosis factor } \alpha \text { ). Also decreased } \\
\text { the elevated malondialdehyde, restored } \\
\text { depleted glutathione, antioxidant } \\
\text { enzymes, superoxide dismutase and } \\
\text { catalase in liver. }\end{array}$ & Embelin. & $\begin{array}{l}\text { Antidiabetic activity may } \\
\text { be due to its potent } \\
\text { antioxidant properties. } \\
\text { Potent antidiabetic } \\
\text { action of Embelia ribes } \\
\text { observed earlier by } \\
\text { many studies may be } \\
\text { due to the presence of } \\
\text { embelin in the extract. }\end{array}$ & [47] \\
\hline 31 & leaves & Hydro-methanol & $\begin{array}{l}\text { Streptozotocin/Oral administration extract } \\
100,200,300 \text { and } 400 \mathrm{mg} / \mathrm{kg} \text { b.w. daily } \\
\text { for } 45 \text { days showed a significant }(P<0.05) \\
\text { decrease in fasting blood glucose and } \\
\text { increase insulin level as compared with the } \\
\text { diabetic rats. Also it significantly }(P<0.05) \\
\text { reduced all biochemical } \\
\text { parameters (serum creatinine, serum } \\
\text { urea, SGOT, SGPT and lipid profile). The } \\
\text { treatment also resulted in } \\
\text { a significant ( } P<0.05) \text { increase in reduced } \\
\text { glutathione, glutathione peroxidase, } \\
\text { superoxide dismutase, } \\
\text { catalase, and decrease LPO level in the } \\
\text { liver and kidney of diabetic rats. }\end{array}$ & $\begin{array}{l}\text { Tannins, phenolic } \\
\text { compounds, and } \\
\text { flavonoids. }\end{array}$ & $\begin{array}{l}\text { Stimulation of insulin } \\
\text { secretion and absorbed } \\
\text { restoration of metabolic } \\
\text { activity. }\end{array}$ & [48] \\
\hline 32 & Seeds & $70 \%$ ethanol & $\begin{array}{l}\text { Streptozotocin/Reduced fasted blood } \\
\text { glucose and serum insulin levels and } \\
\text { oxidative stress in type } 2 \text { diabetic mellitus } \\
\text { rats. Moreover, a significantly hypolipidemic } \\
\text { effect and } \\
\text { an improvement in tissue steatosis could be } \\
\text { observed after the extract administration. }\end{array}$ & Saponins. & $\begin{array}{l}\text { Improving peripheral } \\
\text { insulin resistant rather } \\
\text { than } \\
\text { protecting pancreas islet } \\
\beta \text {-cells and stimulating } \\
\text { insulin secretion. }\end{array}$ & [49] \\
\hline
\end{tabular}


Citation: Kayarohanam S, Kavimani S (2015) Current Trends of Plants Having Antidiabetic Activity: A Review. J Bioanal Biomed 7: 055-065. doi:10.4172/1948-593X.1000124

\begin{tabular}{|c|c|c|c|c|c|c|}
\hline 33 & stem bark & $\begin{array}{l}\text { Alcoholic and } \\
\text { Aqueous }\end{array}$ & $\begin{array}{l}\text { Alloxan/Significantly decreased the blood } \\
\text { glucose level (BGL) in a dose dependent } \\
\text { manner after repeated administration for } 7 \\
\text { days. In alloxan-induced diabetic rats, both } \\
\text { the extracts decreased blood sugar levels } \\
\text { with significant improvement in glucose } \\
\text { tolerance and body weight at the end } \\
\text { of 1st, 2nd and 3rd week after test extract } \\
\text { treatment. }\end{array}$ & $\begin{array}{l}\text { carbohydrates, } \\
\text { alkaloids, flavonoids, } \\
\text { saponins, } \\
\text { phytosterols, } \\
\text { phenolics, tannins, } \\
\text { proteins, amino } \\
\text { acids, fixed oils and } \\
\text { fats. }\end{array}$ & $\begin{array}{l}\text { Insulin mimetic activity } \\
\text { or improved glucose } \\
\text { utilization. }\end{array}$ & {$[50]$} \\
\hline 34 & bark & Methanol & $\begin{array}{l}\text { Streptozotocin/Significant reduction in blood } \\
\text { glucose levels and effect is more in the } \\
\text { dose } 50 \mathrm{mg} / \mathrm{kg} \text { and } 100 \mathrm{mg} / \mathrm{kg} \text { than } 150 \\
\mathrm{mg} / \mathrm{kg} \text {. Also showed significant increase in } \\
\text { serum insulin, body weight, and glycogen } \\
\text { content in liver, skeletal muscle, total } \\
\text { protein contents were markedly increased. } \\
\text { The significant anti-lipid peroxidative effect } \\
\text { in the pancreas. }\end{array}$ & $\begin{array}{l}\text { Lup-20(29)-en-3-yl } \\
\text { acetate, lupeol, } \\
\text { myristicacid,1,3,4,5- } \\
\text { tetrahydroxylcyclohexane } \\
\text { carboxylicacid, } \\
\text { stearicacid,phytol, } \\
\text { sitosterol, and } \\
\text { lanosterolacetate. }\end{array}$ & $\begin{array}{l}\text { Potentiation of } \\
\text { pancreatic secretion } \\
\text { of insulin from existing } \\
\beta \text {-cells of islets by the } \\
\text { significant increase in } \\
\text { the level of insulin. }\end{array}$ & [51] \\
\hline 35 & stem & Alcohol & $\begin{array}{l}\text { Streptozotocin/Significant reduction in } \\
\text { blood glucose levels and improvement in } \\
\text { plasma insulin levels. The effect was more } \\
\text { pronounced in } 100 \text { and } 200 \mathrm{mg} / \mathrm{kg} \text { than } 50 \\
\mathrm{mg} / \mathrm{kg} \text {. The extract } \\
\text { showed significant increase in hexokinase, } \\
\text { Glucose-6-phosphate dehydrogenase and } \\
\text { glycogen content } \\
\text { in liver of diabetic rats and significant } \\
\text { reduction in the levels of glucose- } \\
\text { 6-phosphatase and fructose-1,6- } \\
\text { bisphosphatase. }\end{array}$ & $\begin{array}{l}\text { Gymnemosides and } \\
\text { gymnemic } \\
\text { acid. }\end{array}$ & $\begin{array}{l}\text { Potentiation of } \\
\text { pancreatic secretion } \\
\text { of insulin from existing } \\
\beta \text {-cells of islets and } \\
\text { significant } \\
\text { increase in the level of } \\
\text { insulin. }\end{array}$ & [52] \\
\hline 36 & suspension cell & Ethanol & $\begin{array}{l}\text { Alloxan/ Oral administration of the extracts } \\
\text { reduced the glucose content in blood and } \\
\text { urine, sugar and lipids in serum significantly } \\
(P<0.5) \text { at the same time the extract } \\
\text { increase the body weight, total hemoglobin } \\
\text { and plasma protein content. }\end{array}$ & $\begin{array}{l}\text { Triterpene, saponins } \\
\text { and gymnemic } \\
\text { acids (I-XVIII and } \\
\text { gymnemosaponins } \\
(I-V) .\end{array}$ & $\begin{array}{l}\text { Potentiating the insulin } \\
\text { effect of plasma by } \\
\text { increasing either the } \\
\text { pancreatic section in } \\
\text { insulin form } \beta \text {-cell or its } \\
\text { release bound form. }\end{array}$ & [53] \\
\hline 37 & Whole plant & Alcohol & $\begin{array}{l}\text { Streptozotocin/ Significant increase in the } \\
\text { body weight and decrease in blood glucose } \\
\text { level with higher antioxidant capacity, good } \\
\text { reducing power, scavenger of reactive } \\
\text { oxygen like DPPH, nitric acid, hydrogen } \\
\text { peroxide and deoxyribose. }\end{array}$ & $\begin{array}{l}\text { Tannins, } \\
\text { Flavonoids, } \\
\text { vitamin-C and } \\
\text { vitamin-E. }\end{array}$ & $\begin{array}{l}\text { Enhance the peripheral } \\
\text { utilisation of glucose. }\end{array}$ & [54] \\
\hline 38 & leaves & $\begin{array}{l}\text { Ethanol and } \\
\text { Aqueous }\end{array}$ & $\begin{array}{l}\text { Streptozotocin/ln showed an outstanding } \\
\text { hypoglycaemic effect at } \\
500 \text { and } 1000 \mathrm{mg} / \mathrm{kg} \text { doses, } 1-4 \mathrm{~h} \text { after the } \\
\text { administration. } \\
\text { In oral glucose tolerance test, glucose } \\
\text { solution was loaded to normal rats just after } \\
30^{\text {th }} \text { minute measurement. The ethanol } \\
\text { extract, given in } 1000 \mathrm{mg} / \mathrm{kg} \text {, was found } \\
\text { more effective }(3.2-11.7 \%) \text {. }\end{array}$ & $\begin{array}{l}\text { Terpenoids, fatty } \\
\text { acids and other } \\
\text { hydrocarbons. }\end{array}$ & $\begin{array}{l}\text { Effect in insulin secretion } \\
\text { or } \\
\text { insulin like activity. } \\
\text { Rising sensitivity of } \\
\text { PPAR- y receptors by } \\
\text { increasing the } \\
\text { release of insulin from } \beta \\
\text { cells of pancreas. }\end{array}$ & [55] \\
\hline 39 & flowers & Petroleum ether & $\begin{array}{l}\text { Streptozotocin/ } 21 \text { days of oral } \\
\text { administration of extract significantly } \\
\text { reduced the blood glucose, serum } \\
\text { cholesterol and triglycerids levels. At the } \\
\text { same time the high density lipoprotein level } \\
\text { was found to be improved }(P<0.01) \text {. }\end{array}$ & $\begin{array}{l}\text { Iridoids, flavonoids, } \\
\text { naphthoquinones, } \\
\text { and volatile } \\
\text { constituent. }\end{array}$ & $\begin{array}{l}\text { Enhance insulin } \\
\text { activation. }\end{array}$ & [56] \\
\hline 40 & Whole plant & Methanol & $\begin{array}{l}\text { Streptozotocin/ Significant decrease in blood } \\
\text { glucose and glycosylated hemoglobin with a } \\
\text { significant increase in plasma insulin level, } \\
\text { body weight and food intake. Furthermore } \\
\text { Y-sitosterol showed anti-hyperlipidemic } \\
\text { activity as evidenced by significant decrease } \\
\text { in serum total cholesterol, triglycerides and } \\
\text { very low density lipoprotein-cholesterol } \\
\text { levels coupled with elevation of high density } \\
\text { lipoprotein-cholesterol levels. A significant } \\
\text { decrease in the alanine aminotransaminase, } \\
\text { aspartate aminotransaminase, alkaline } \\
\text { phosphatase and acid phosphatase in } \\
Y \text {-sitosterol treated rats when compared to } \\
\text { diabetic control rats } \\
\text { indicated its protective role against liver } \\
\text { damage. }\end{array}$ & $\begin{array}{l}\text { Glycosides, lippiflorin } \\
\text { A and B, nodiflorin } \\
\text { A and B, alkaloids, } \\
\text { essential oil, } \\
\text { resin, stigmasterol, } \\
\text { beta-sitosterol, } \\
\text { sugars, mono and } \\
\text { diflavone sulphates } \\
\text { of neptin, jaceosidin, } \\
\text { hispidulin and } \\
\text { 6-hyfroxy- luteolin. }\end{array}$ & Regeneration of $\beta$-cells. & [57] \\
\hline
\end{tabular}


Citation: Kayarohanam S, Kavimani S (2015) Current Trends of Plants Having Antidiabetic Activity: A Review. J Bioanal Biomed 7: 055-065. doi:10.4172/1948-593X.1000124

\begin{tabular}{|c|c|c|c|c|c|c|}
\hline 41 & Leaves & $\begin{array}{l}\text { Aqueous } \\
\text { Methanol }(90 \%)\end{array}$ & $\begin{array}{l}\text { Alloxan/Significant }(P<0.05, P<0.001) \\
\text { dose related reduction in blood glucose } \\
\text { concentration when compared to } \\
\text { glibenclamide. }\end{array}$ & $\begin{array}{l}\text { Glycosides, } \\
\text { flavonoids, } \\
\text { proteins, resins, } \\
\text { oils, steroids, } \\
\text { terpenoids, alkaloids } \\
\text { tannins and saponins. }\end{array}$ & $\begin{array}{l}\text { Immunostimulatory } \\
\text { effect and protect the } \\
\text { pathological damages } \\
\text { secondary to the diabetic } \\
\text { complications. The } \\
\text { antidiabetic activity } \\
\text { is evidently due to } \\
\text { flavonoid content of the } \\
\text { plant. }\end{array}$ & [58] \\
\hline 42 & Aerial part & Aqueous & $\begin{array}{l}\text { Alloxan/Significant effect antidiabetic and } \\
\text { antihyperlipidemic } \\
\text { (dose-dependent effect). A decrease in } \\
\text { blood glucose by } 50 \% \text { for the dose } 100 \mathrm{mg} / \\
\mathrm{kg} \text { and more than } 60 \% \text { for doses } 200 \text { and } \\
300 \mathrm{mg} / \mathrm{kg} \text { twice daily for } 2 \text { weeks showed } \\
\text { the best decrease in the blood glucose level } \\
\text { comparable to the effects of glibenclamide, } \\
\text { as well as a significant lowering of total } \\
\text { lipids, triglycerides, and total cholesterol } \\
\text { levels in treated animals, compared with } \\
\text { diabetic controls group ( } p<0.001 \text { ), have } \\
\text { been observed. }\end{array}$ & $\begin{array}{l}\text { 5-O-caffeoylquinic, } \\
\text { apigenin } 6,8 \\
\text { di-C-glucoside, } \\
\text { ballotetroside, } \\
\text { verbascoside- } \\
\text { pentoside, } \\
\text { verbascoside- } \\
\text { pentoside, } \\
\text { alyssonoside, luteolin } \\
\text { O-glucuronide, } \\
\text { apigenin O-glucoside, } \\
\text { crysoeriol } \\
\text { O-glucuronide, } \\
\text { ladanein, flavonoids } \\
\text { and cinnamic acid. } \\
\end{array}$ & $\begin{array}{l}\text { Stimulation of insulin } \\
\text { secretion from } \beta \text { cells of } \\
\text { islets by } \\
\text { inhibition of insulin } \\
\text { degradation processes. }\end{array}$ & [59] \\
\hline 43 & Leaves & Ethanol & $\begin{array}{l}\text { Alloxan/Significant reduction in fasting } \\
\text { blood glucose }(\mathrm{P}<0.001) \text { in acute and } \\
\text { prolonged treatment }(2 \text { weeks). The } \\
\text { activities of extract more than the } \\
\text { reference drug glibenclamide. The extract } \\
\text { also significantly reduced the levels of } \\
\text { serum, total cholesterol, LDL, VLDL, and } \\
\text { triglycerides, at the same time increase in } \\
\text { HDL levels. }\end{array}$ & $\begin{array}{l}\text { Terpenes, saponins, } \\
\text { tannins and alkaloids. }\end{array}$ & $\begin{array}{l}\text { Hypoglycaemic action } \\
\text { by potentiating the } \\
\text { insulin effect, either } \\
\text { by stimulating the } \\
\text { pancreatic secretion of } \\
\text { insulin from the cells } \\
\text { of islets langerhans or } \\
\text { its release from bound } \\
\text { insulin. }\end{array}$ & {$[60]$} \\
\hline 44 & Whole plant & Methanol & $\begin{array}{l}\text { Streptozotocin/Significant decrease in blood } \\
\text { glucose, serum urea and serum creatinine } \\
\text { and increases in body weight insulin and } \\
\text { protein level and total hemoglobin level. } \\
\text { Significantly decrease the glucose }-6 \\
\text { phosphates, fructose-1, } 6 \text { - bi-phosphates. } \\
\text { Histology of diabetic rated trated with the } \\
\text { plant extract showed the pancreatic } \beta \text { cell } \\
\text { regeneration. }\end{array}$ & $\begin{array}{l}\text { Terpenes, steroids, } \\
\text { polyphenols, } \\
\text { glycosides, } \\
\text { flavanoids, } \\
\text { carbohydrates and } \\
\text { proteins. }\end{array}$ & $\begin{array}{l}\text { Stimulates insulin } \\
\text { secretion from the } \\
\text { remnant } \beta \text {-cells or from } \\
\text { regenerated } \beta \text {-cells }\end{array}$ & {$[61,62]$} \\
\hline 45 & root & Aqueous & $\begin{array}{l}\text { Streptozotocin/The antidiabetic effects } \\
\text { were compared with glibenclamide and the } \\
\text { plant extract produced the more significant } \\
\text { reduction of blood glucose in the dose } \\
100 \text { and } 150 \mathrm{mg} / \mathrm{kg} \text { then } 50 \mathrm{mg} / \mathrm{kg} \text {. It also } \\
\text { produce significant reduction in the levels of } \\
\text { serum triglyceride and total cholesterol. }\end{array}$ & $\begin{array}{l}\text { Flavonoids, } \\
\text { diosmetin, luteolin } \\
\text { and 7-O- } \beta-D- \\
\text { glucosides. }\end{array}$ & $\begin{array}{l}\text { Potentiating the } \\
\text { pancreatic secretion } \\
\text { of insulin from existing } \\
\beta \text {-cells of islets by } \\
\text { increasing the level of } \\
\text { insulin. }\end{array}$ & [63] \\
\hline 46 & Whole plant & Ethanol & $\begin{array}{l}\text { Streptozotocin/Administration of } 5 \mathrm{mg} / \mathrm{kg} \\
\text { of plant extract, blood glucose levels of the } \\
\text { non insulin dependent diabetes mellitus } \\
\text { rats showed } 62.00 \text { and } 76.29 \% \text { decrease in } \\
\text { the blood glucose levels on day } 0 \text { and day } \\
30 \text { respectively. Damages caused to the } \\
\text { kidney tissue were negligible or not seen. } \\
\text { Serum urea and creatinine levels showed } \\
61.49 \text { and } 70.96 \% \text { decrease on day } 30 . \\
\text { LPP levels of kidney and pancreas showed } \\
70.58 \text { and } 77.41 \% \text { decrease respectively. }\end{array}$ & - & $\begin{array}{l}\text { Regeneration } \\
\text { of epithelium, } \\
\text { expansion of glomeruli, } \\
\text { disappearance of } \\
\text { haemorrhages and } \\
\text { cytoplasmic debris, } \\
\text { decrease in the levels of } \\
\text { serum urea and creatinine } \\
\text { were the major changes } \\
\text { observed besides } \\
\text { lowering blood glucose }\end{array}$ & [64] \\
\hline 47 & $\begin{array}{l}\text { Oligosaccharides } \\
\text { of the plant }\end{array}$ & $\begin{array}{l}\text { Isolation of } \\
\text { oligosaccharides }\end{array}$ & $\begin{array}{l}\text { Streptozotocin/Increase body weight, } \\
\text { decrease organ related weights of liver } \\
\text { and kidney, reduce fasting blood glucose } \\
\text { level, and improve oral glucose tolerance } \\
\text { in diabetic rats. Moreover, increased } \\
\text { glycogen content in liver and skeletal } \\
\text { muscle, reduced urinary protein excretion, } \\
\text { higher hepatic GCK enzyme activity, lower } \\
\text { hepatic PEPCK enzyme activity, enhanced } \\
\text { GLP-1 level, decreased glucagon level } \\
\text { and alleviated histopathological changes } \\
\text { of pancreas occurred in extract treated } \\
\text { diabetic rats by comparison with untreated } \\
\text { diabetic rats. }\end{array}$ & Oligosaccharides. & $\begin{array}{l}\text { Increase the } \beta \text {-cell mass } \\
\text { by inhibiting apoptosis. } \\
\text { Stimulates insulin } \\
\text { synthesis and release. }\end{array}$ & [65] \\
\hline
\end{tabular}




\begin{tabular}{|c|c|c|c|c|c|c|}
\hline 48 & Cladodes & $80 \%$ ethanol & $\begin{array}{l}\text { Streptozotocin/Significantly decreased } \\
\text { (P<0.05) the fasting levels of blood glucose } \\
(\mathrm{BG}) \text {, total cholesterol (TC), triglycerides } \\
\text { (TGs), plasma urea nitrogen (PUN), and } \\
\text { malondialdehyde (MDA); and the activity } \\
\text { of glucose-6-phosphatase (G-6-Pase). In } \\
\text { contrast, it significantly increased (P<0.05) the } \\
\text { body weights, hepatic glycogen (HG) levels, } \\
\text { high-density lipoprotein cholesterol (HDL-C) } \\
\text { levels, and the hepatic superoxide dismutase } \\
\text { (SOD) and glutathione peroxidase (GSH-Px) } \\
\text { activity in diabetic mice. }\end{array}$ & $\begin{array}{l}\text { Polysaccharides, } \\
\text { betalains, phenolic } \\
\text { compounds, organic } \\
\text { acids, lipids, } \\
\text { minerals, vitamins, } \\
\text { amino acids and } \\
\text { taurine. }\end{array}$ & $\begin{array}{l}\text { Overproduction of } \\
\text { excessive hepatic } \\
\text { glycogenolysis, } \\
\text { gluconeogenesisand } \\
\text { decreases the utilization } \\
\text { of glucose by the } \\
\text { tissues. }\end{array}$ & [66] \\
\hline 49 & Whole plant & Chloroform & $\begin{array}{l}\text { Streptozotocin/Significant lowering } \\
(p<0.05) \text { of the final blood glucose level } \\
\text { compared to the pretreatment level. No } \\
\text { significant differences in the plasma } \\
\text { insulin levels post-treatment compared to } \\
\text { the pretreatment levels and significantly } \\
\text { increased }(p<0.001) \text { the glucose uptake by } \\
\text { the rat diaphragm muscle. }\end{array}$ & $\begin{array}{l}\text { Isopimarane- } \\
\text { type diterpenes, } \\
\text { orthosiphols A-E, } \\
\text { monoterpenes, } \\
\text { triterpenes, saponins, } \\
\text { flavonoids, hexoses, } \\
\text { organic acids, } \\
\text { rosmarinic acid, } \\
\text { chromene, myo- } \\
\text { inositolm flavonoids } \\
\text { and terpenoids. }\end{array}$ & $\begin{array}{l}\text { Direct insulin-like effect } \\
\text { on the utilization of } \\
\text { glucose by increasing } \\
\text { the membrane transport } \\
\text { of glucose in peripheral } \\
\text { tissues. }\end{array}$ & [67] \\
\hline 50 & Root & $\begin{array}{l}\text { Ethanol and } \\
\text { aqueous }\end{array}$ & $\begin{array}{l}\text { Streptozotocin/Significantly }(P<0.001) \\
\text { reduced the blood glucose at the dose } 250 \\
\mathrm{mg} / \mathrm{kg} \text {. }\end{array}$ & $\begin{array}{l}\text { Carbohydrates, } \\
\text { proteins, aminoacids, } \\
\text { saponins, } \\
\text { tannins,phenolic } \\
\text { compounds, alkaloids } \\
\text { and flavonoids. }\end{array}$ & $\begin{array}{l}\text { The mechanism of these } \\
\text { hypoglycemic effects } \\
\text { of the extracts is not } \\
\text { elucidated in this study. }\end{array}$ & [68] \\
\hline
\end{tabular}

Table 1: Review of medicinal plants with antidiabetic potential.

diabetes deaths occur in low- and middle-income countries [75]. Antidiabetic drugs used as mono-therapy or in combination to achieve better glycemic control. Each of the oral antidiabetic agents is however, associated with a number of serious adverse effects $[76,77]$ and none of the antidiabetic drugs could give a long term glycaemic control without cousin the side effects [78]. Plant based drugs have been known to be safe and cheaper and the plant play the major role to manage the diabetes mellitus [79-81]. World health organisation (WHO) has recommended the evaluation of traditional plant treatments for diabetes as they are effective, non-toxic, which less or no side effects and are considered to be a valuable source for the investigation of hypoglycaemic agents [82,83]. According to world ethnobotanical information reports, almost 800 plants possess antidiabetic potential [84]. Several reviews on the plants used in the management of diabetes have been reported in the past [85-92].The current review showed that plants possessed antidiabetic property and may of the study not properly mention the precise mechanism of the plant and the active compound responsible for the antidiabetic effect. This may be explained by the nature of extracts and lack of in vivo methods. Most of the authors explained that the mechanism of the plant extract is the same as that of standard drugs and that the antidiabetic effect is due to the antioxidant property of the plants $[18,23,39,47]$. Some other authors had mentioned the mechanism of the plant is by increasing the insulin secretion by stimulating the $\beta$ cell $[51-55,62-65]$. However the exact mechanism is very challenging to identified and explained in proper manner. Streptozotocin and alloxan induced diabetes model is used as a screening method for anti-diabetic drugs and many other animal models have been developed and described for the screening of anti-diabetic drugs, but none of them is exactly equivalent to human diabetes [93]. Plant products are known to be rich in phenolic compounds, flavonoids, terpenoids, coumarins and other constituents which reduce blood glucose levels [94,95]. In the current review most of the plants have the flavonoid, and terpenoids may be the reason for reducing the blood glucose level in animals. In Africa, hundreds of plants are used traditionally for the management of diabetes mellitus, but only few of the plants have been scientifically validated $[96,97]$.
The variety of phytoconstituent classes and the wide differences in the molecular structure of the isolated compounds suggest the possibility of different mechanisms of action in lowering blood glucose [98]. So, the identification of phytochemical is not only enough, at the same time prove the exact mechanism and clinical trial is essentially need to use the plant drug clinically.

\section{Conclusion}

The study found that since the antidiabetic evaluation is done using extracts. It may be difficult to find the exact mechanism responsible for the hypoglycemic effect. Studies are needed to identify the active compound responsible for the hypoglycemic effect. Although numerous medicinal plants have anti diabetic effect, phytochemical and clinical research work on the discovered plant species is yet to be done. Every plant material is not safe, so need to investigate the toxic effect of these plants before consumption. Isolate and test the active components from the potent active antidiabetic plant and there is the essential need for clinical research on the new drug available in the market with less side effects.

\section{Acknowledgments}

The authors would like to acknowledge Sa'adiah Bt. Mohd. Yusoff .

\section{References}

1. WHO (1999) Definition, Diagnosis and Classification of Diabetes Mellitus and its Complications, Report of a WHO Consultation Part 1. Diagnosis and Classification of Diabetes Mellitus, Geneva, p.2.

2. Danaei G, Finucane MM, Lu Y, Singh GM, Cowan MJ, et al. (2011) National, regional, and global trends in fasting plasma glucose and diabetes prevalence since 1980: systematic analysis of health examination surveys and epidemiological studies with 370 country-years and 2.7 million participants. Lancet 378: 31-40.

3. Anonymous (2006) Diabetes Atlas (3rdedtn.) International Diabetes Federation Brussels.

4. Mathers CD, Loncar D (2006) Projections of global mortality and burden of disease from 2002 to 2030 . PLoS Med 3: e442. 
Citation: Kayarohanam S, Kavimani S (2015) Current Trends of Plants Having Antidiabetic Activity: A Review. J Bioanal Biomed 7: 055-065. doi:10.4172/1948-593X.1000124

5. World Health Organization (2011) Global status report on noncommunicable diseases 2010. Geneva, pp. 1-176.

6. World Health Organization Geneva (2002-2005) Traditional Medicine Strategy pp. 1-3.

7. Grover JK, Vats V, Rathi SS (2000) Anti-hyperglycemic effect of Eugenia jambolana and Tinospora cordifolia in experimental diabetes and their effects on key metabolic enzymes involved in carbohydrate metabolism. J Ethnopharmacol 73: 461-470

8. Grover JK, Vats V, Rathi SS, Dawar R (2001) Traditional Indian anti-diabetic plants attenuate progression of renal damage in streptozotocin induced diabetic mice. J Ethnopharmacol 76: 233-238.

9. Grover JK, Yadav S, Vats V (2002) Medicinal plants of India with anti-diabetic potential. J Ethnopharmacol 81: 81-100.

10. Warier PK, Momordica CLI, Warrier PK, Nambiar VPK, Ramankutty C (1995) Indian Medicinal Plants, Orient Longman, Chennai, pp. 48-51.

11. Kar A, Choudhary BK, Bandyopadhyay NG (2003) Comparative evaluation of hypoglycaemic activity of some Indian medicinal plants in alloxan diabetic rats. J Ethnopharmacol 84: 105-108.

12. Alarcon-Aguilara FJ, Roman-Ramos R, Perez-Gutierrez S, Aguilar-Contreras A, Contreras-Weber CC, et al. (1998) Study of the anti-hyperglycemic effect of plants used as antidiabetics. J Ethnopharmacol 61: 101-110.

13. World Health Organization (1999) Consultation Meeting on Traditional Medicine and Modern Medicine: Harmonizing the Two Approaches. Geneva.

14. World Health Organization (1999) Traditional, Complementary and Alternative Medicines and Therapies. Washington DC, WHO Regional Office for the Americas/Pan American Health Organization.

15. World Health Organization Report (1998) Technical Briefing on Traditional Medicine. Forty-ninth Regional Committee Meeting, Manila, Philippines.

16. Fisher P, Ward A (1994) Complementary medicine in Europe. BMJ 309: 107111.

17. Health Canada (2001) Perspectives on Complementary and Alternative Health Care: A Collection of Papers Prepared for Health Canada. Health Canada, Ottawa, Health Canada.

18. Jianfang $F$, Jufang $F$, Jun $Y$, Nanyan Z, Bin G, et al. (2012) Anti-Diabetic activities of Acanthopanax senticosus polysaccharide (ASP) in combination with metformin. International Journal of Biological Macromolecules 50: 619623

19. Prisilla DH, Balamurugan R, Shah HR (2012) Antidiabetic activity of methanol extract of Acorus calamus in STZ induced diabetic rats. Asian Pacific Journal of Tropical Biomedicine 2: S941-S946.

20. Prashant C, Bharat G, Ashoke KG (2012) Antidiabetic activity of Adina cordifolia (Roxb) leaves in alloxan induced diabetic rats. Asian Pacific Journal of Tropical Biomedicine 2: S1630-S1632.

21. Naskar S, Mazumder UK, Pramanik G, Gupta M, Kumar RB, et al. (2011) Evaluation of antihyperglycemic activity of Cocos nucifera Linn. on streptozotocin induced type 2 diabetic rats. J Ethnopharmacol 138: 769-773.

22. Oyedemi SO, Adewusi EA, Aiyegoro OA, Akinpelu DA (2011) Antidiabetic and haematological effect of aqueous extract of stem bark of Afzelia africana (Smith) on streptozotocin-induced diabetic Wistar rats. Asian Pac J Trop Biomed 1: 353-358

23. Rajesh K, Dinesh KP, Satyendra KP, Kirshnamurthy S, Siva H (2011) Antidiabetic activity of alcoholic leaves extract of Alangium lamarckii Thwaites on streptozotocin-nicotinamide induced type 2 diabetic rats. Asian Pacific Journal of Tropical Medicine 4: 904-909.

24. Dinesh K, Sunil K, Sonia K, Renu A, Jyoti G (2011) Antidiabetic activity of methanolic bark extract of Albizia odoratissima Benth in alloxan induced diabetic albino mice. Asian Pacific Journal of Tropical Medicine 4: 900-903.

25. Girija K, Lakshman K, Udaya C, Sabhya SG, Divya T (2011) Anti-diabetic and anti-cholesterolemic activity of methanol extracts of three species of Amaranthus. Asian Pac J Trop Biomed 1: 133-138.

26. Ramdas P, Sangameswaran B, Popat M, Shantaram K (2012) Antidiabetic and antihyperlipidaemic potential of Amaranthus viridis (L.) Merr in streptozotocin induced diabetic rats. Asian Pacific Journal of Tropical Disease 2: S180-S185.
27. Subramaniam R, Koikaramparambil RN, Baskaran R, Mohammad A (2012) Antidiabetic, antihyperlipidemic and in vivo antioxidant potential of aqueous extract of Anogeissus latifolia bark in type 2 diabetic rats. Asian Pacific Journal of Tropical Disease 2: S596-S602.

28. Olubomehin OO, Abo KA, Ajaiyeoba EO (2013) Alpha-amylase inhibitory activity of two Anthocleista species and in vivo rat model anti-diabetic activities of Anthocleista djalonensis extracts and fractions. J Ethnopharmacol 146: 811 814

29. Okokon JE, Antia BS, Udobang JA (2012) Antidiabetic activities of ethanolic extract and fraction of Anthocleista djalonensis. Asian Pac J Trop Biomed 2: 461-464.

30. Ibeh BO, Ezeaja MI (2011) Preliminary study of antidiabetic activity of the methanolic leaf extract of Axonopus compressus ( $P$. Beauv) in alloxan-induced diabetic rats. J Ethnopharmacol 138: 713-716.

31. Das SN, Patro VJ, Dinda SC (2012) Evaluation of Anti-Inflammatory, Antidiabetic activityof Indian Bauhinia vahlii (stembark). Asian Pacific Journal of Tropical Biomedicine 2: S1382-S1387.

32. Sunil J, Kumar Y, Khan MSY (2012) Hypoglycemic activities of Bougainvillea spectabilis stem bark in normal and alloxan-induced diabetic rats. Asian Pacific Journal of Tropical Biomedicine 2: S919-S923.

33. Adisa RA, Choudhary MI, Olorunsogo OO (2011) Hypoglycemic activity of Buchholzia coriacea (Capparaceae) seeds in streptozotocin-induced diabetic rats and mice. Experimental and Toxicologic Pathology 63: 619-625.

34. Kumar R, Patel DK, Prasad SK, Sairam K, Hemalatha S (2012) Antidiabetic activity of alcoholic root extract of Caesalpinia digyna in streptozotocinnicotinamide induced diabetic rats. Asian Pacific Journal of Tropical Biomedicine 2: S934-S940.

35. Nazreen S, Kaur G, Alam MM, Shafi S, Hamid H, et al. (2012) New flavones with antidiabetic activity from Callistemon lanceolatus DC. Fitoterapia 83: 16231627.

36. Abeywickrama KRW, Ratnasooriya WD, Amarakoon AMT (2011) Ora hypoglycaemic, antihyperglycaemic and antidiabetic activities of Sri Lankan Broken Orange Pekoe Fannings (BOPF) grade black tea (Camellia sinensis L.) in rats. Journal of Ethnopharmacology 135: 278-286.

37. Itankar PR, Lokhande SJ, Verma PR, Arora SK, Sahu RA, et al. (2011) Antidiabetic potential of unripe Carissa carandas Linn. fruit extract. J Ethnopharmacol 135: 430-433.

38. Yuntao L, Jun S, Shengqi R, Yujie S, Yanjun Y (2013) Antihyperglycemic antihyperlipidemic and antioxidant activities of polysaccharides from Catathelasma ventricosum in streptozotocin-induced diabetic mice. Food and Chemical Toxicology 57: 39-45.

39. Sandesh S, Shruti S, Sung-Yum S (2013) Antidiabetic and antiacetylcholinesterase effects of ethyl acetate fraction of Chaenomeles sinensis (Thouin) Koehne fruits in streptozotocin-induced diabetic rats. Experimental and Toxicologic Pathology 65: 55-60.

40. Gorelick J, Kitron A, Pen S, Rosenzweig T, Madar Z (2011) Anti-diabetic activity of Chiliadenus iphionoides. J Ethnopharmacol 137: 1245-1249.

41. Orhan N, Aslan M, Şüküroğlu M, Deliorman Orhan D (2013) In vivo and in vitro antidiabetic effect of Cistus laurifolius $\mathrm{L}$. and detection of major phenolic compounds by UPLC-TOF-MS analysis. J Ethnopharmacol 146: 859-865.

42. Sunil C, Agastian P, Kumarappan C, Ignacimuthu S (2012) In vitro antioxidant antidiabetic and antilipidemic activities of Symplocos cochinchinensis (Lour.) S. Moore bark. Food Chem Toxicol 50: 1547-1553.

43. Bellamkonda R, Rasineni K, Singareddy SR, Kasetti RB, Pasurla R, et al. (2011) Antihyperglycemic and antioxidant activities of alcoholic extract of Commiphora mukul gum resin in streptozotocin induced diabetic rats. Pathophysiology 18 : 255-261.

44. Clautilde MT, Boudjeko T, Bruno TT, Pascaline CM, Denis Z (2013) Antihyperglycaemic globulins from selected Cucurbitaceae seeds used as antidiabetic medicinal plants in Africa. BMC Complementary and Alternative Medicine 13: 63

45. Devi M, Latha P (2013) Antidiabetic effect of methanolic extract of Decalepis hamiltonii root (wight and Arn) in normal and alloxan induced diabetic rats. Journol of pharmacy research 61:66-172.

46. Sunil K, Vipin K, Om P (2011) Antidiabetic, hypolipidemic and histopathological 
analysis of Dillenia indica (L.) leaves extract on alloxan induced diabetic rats. Asian Pacific Journal of Tropical Medicine 4: 347-352.

47. Mahendran S, Badami S, Maithili V (2011) Evaluation of antidiabetic effect of embelin from Embelia ribes in alloxan induced diabetes in rats. Biomedicine \& Preventive Nutrition 1: 25-31.

48. Nain P, Saini V, Sharma S, Nain J (2012) Antidiabetic and antioxidant potential of Emblica officinalis Gaertn. leaves extract in streptozotocin-induced type-2 diabetes mellitus (T2DM) rats. J Ethnopharmacol 142: 65-71.

49. Zheng T, Shu G, Yang Z, Mo S, Zhao Y, et al. (2012) Antidiabetic effect of total saponins from Entada phaseoloides (L.) Merr. in type 2 diabetic rats. J Ethnopharmacol 139: 814-821.

50. Yashwant Kumar A, Nandakumar K, Handral M, Talwar S, Dhayabaran D (2011) Hypoglycaemic and anti-diabetic activity of stem bark extracts Erythrina indica in normal and alloxan-induced diabetic rats. Saudi Pharm J 19: 35-42.

51. Arunachalam K, Parimelazhagan T (2013) Antidiabetic activity of Ficus amplissima Smith. bark extract in streptozotocin induced diabetic rats. J Ethnopharmacol 147: 302-310.

52. Ramkumar KM, Vanitha $P$, Uma C, Suganya N, Bhakkiyalakshmi $E$, et al. (2011) Antidiabetic activity of alcoholic stem extract of Gymnema montanum in streptozotocin-induced diabetic rats. Food Chem Toxicol 49: 3390-3394

53. Karthic R, Nagaraj S, Arulmurugan P, Seshadri S, Rengasamy R, et al. (2012) Gymnema sylvestre $\mathrm{R}$. Br. suspension cell extract show antidiabetic potential in Alloxan induced diabetic albino male rats. Asian Pacific Journal of Tropical Biomedicine 2: S930-S933.

54. Patel DK, Kumar R, Prasad SK, Sairam K, Hemalatha S (2011) Antidiabetic and in vitro antioxidant potential of Hybanthus enneaspermus (Linn) F. Muell in streptozotocin-induced diabetic rats. Asian Pac J Trop Biomed 1: 316-322.

55. Orhan N, Aslan M, Demirci B, Ergun F (2012) A bioactivity guided study on the antidiabetic activity of Juniperus oxycedrus subsp. oxycedrus L. leaves. J Ethnopharmacol 140: 409-415.

56. Kumar S, Kumar V, Prakash OM (2012) Antidiabetic and hypolipidemic activities of Kigelia pinnata flowers extract in streptozotocin induced diabetic rats. Asian Pac J Trop Biomed 2: 543-546.

57. Rangachari B, Savarimuthu I (2011) Antidiabetic and Hypolipidemic effect of methanol extract of Lippia nodiflora $\mathrm{L}$. in streptozotocin induced diabetic rats. Asian Pacific Journal of Tropical Biomedicine 1: S30-S36.

58. Patience OO, Edwin OO, Sylvester CN, Charles OE, Philip FU, et al. (2010) Antidiabetic principles of Loranthus micranthus Linn. parasitic on Persea Americana. Asian Pacific Journal of Tropical Medicine 3: 619-623.

59. Boudjelal A, Henchiri C, Siracusa L, Sari M, Ruberto G (2012) Compositional analysis and in vivo anti-diabetic activity of wild Algerian Marrubium vulgare $L$. infusion. Fitoterapia 83: 286-292.

60. Akpan EJ, Okokon JE, Offong E (2012) Antidiabetic and hypolipidemic activities of ethanolic leaf extract and fractions of Melanthera scandens. Asian Pac J Trop Biomed 2: 523-527.

61. Purushoth P, Suresh R, Selvakumari S (2012) Phytochemical Analysis of Ethanolic Extract of Merremia emaraginata Burm. F by GC-MS. RJBCPS 10: 3

62. Gandhi GR, Sasikumar P (2012) Antidiabetic effect of Merremia emarginata Burm. F. in streptozotocin induced diabetic rats. Asian Pac J Trop Biomed 2: 281-286.

63. Arunachalam K, Parimelazhagan T (2012) Antidiabetic activity of aqueous root extract of Merremia tridentata (L.) Hall. f. in streptozotocin-induced-diabetic rats. Asian Pac J Trop Med 5: 175-179.

64. Kumar EK, Janardhana GR (2011) Antidiabetic activity of alcoholic stem extract of Nervilia plicata in streptozotocin-nicotinamide induced type 2 diabetic rats. $J$ Ethnopharmacol 133: 480-483.

65. Li PB, Lin WL, Wang YG, Peng W, Cai XY, et al. (2012) Antidiabetic activities of oligosaccharides of Ophiopogonis japonicus in experimental type 2 diabetic rats. Int J Biol Macromol 51: 749-755.

66. Zhao LY, Lan QJ, Huang ZC, Ouyang LJ, Zeng FH (2011) Antidiabetic effect of a newly identified component of Opuntia dillenii polysaccharides. Phytomedicine 18: 661-668.

67. Elsnoussi AHM, Mun FY, Lee FA, Ali JM, Mohd ZA (2013) Antidiabetic Properties and Mechanism of Action of Orthosiphon stamineus Benth Bioactive
Sub-fraction in Streptozotocin-induced Diabetic Rats. J Acupunct Meridian Stud 6: 31-40.

68. Jothimni R, Karthikeyan K, Balasundaram J (2012) Antidiabetic activity and chemical characterization of aqueous/ethanol prop roots extracts of Pandanus fascicularis Lam in streptozotocininduced diabetic rats. Asian Pacific Journal of Tropical Biomedicine 2: S170-S174

69. Zimmet P, Cowie C, Ekoe JM, Shaw J (2004) Classification of diabetes mellitus and other categories of glucose intolerance. In: International Textbook of Diabetes Mellitus.

70. King H, Aubert RE, Herman WH (1998) Global burden of diabetes 1995-2025 prevalence, numerical estimates, and projection. Diabetes Care 21: 1414-1431.

71. Oyedemi SO, Adewusi EA, Aiyegoro OA, Akinpelu DA (2011) Antidiabetic and haematological effect of aqueous extract of aqueous extract of stem bark of Afzelia africana (Smith) on streptozotocin-induced diabetic Wister rats. Asian pacific Journol of Tropical Biomedicine 1: 353-358.

72. World Health Organization (1994) Prevention of diabetes mellitus: report of a WHO Study Group. Geneva.

73. Sandoval S (2009) Pima Indian Diabetes susceptibility differs significantly from European susceptibility. Biochem 118: 1-8.

74. Arky RA (1982) Clinical correlates of metabolic derangements of diabetes mellitus. Complications of diabetes mellitus. W.B. Saunders, Philadelphia, pp. 16-20.

75. World Health Organization (2009) Fact Sheet 312.

76. Moller DE (2001) New drug targets for type 2 diabetes and the metabolic syndrome. Nature 414: 821-827.

77. Nwaegerue E, Nweke IN, Ezeala CC, Unekwe PC (2007) Glucose lowering effect of leaf extracts of Viscum album in normal and diabetic rats. Journal of Research in Medical Sciences 12: 235-240.

78. Singh S, Loke YK, Furberg CD (2007) Thiazolidinediones and heart failure: a teleo-analysis. Diabetes Care 30: 2148-2153.

79. Ahmed I, Adeghate E, Cummings E, Sharma AK, Singh J (2004) Beneficial effects and mechanism of action of Momordica charantia juice in the treatment of streptozotocin-induced diabetes mellitus in rat. Mol Cell Biochem 261: 63-70.

80. Karunanayake EH, Tennekoon KH (1993) Search of novel hypoglycaemic agents from medicinal plants. In: Sharma AK. Diabetes mellitus and its complications. An update. Macmillan India Ltd, New Delhi, India.

81. Ribnicky DM, Kuhn P, Poulev A, Logendra S, Zuberi A, et al. (2009) Improved absorption and bioactivity of active compounds from an anti-diabetic extract of Artemisia dracunculus L. Int J Pharm 370: 87-92.

82. Platel K, Srinivasan K (1997) Plant foods in the management of diabetes mellitus: vegetables as potential hypoglycaemic agents. Nahrung 41: 68-74.

83. Kumar S, Rashmi Kumar D (2010) Evaluation of antidiabetic activity of Euphorbia hirta Linn. In streptozotocin induced induced diabetic mice. Indian J Nat Prod Resour 1: 200-203.

84. Alarcon-Aguilara FJ, Roman-Ramos R, Perez-Gutierrez S, Aguilar-Contreras A, Contreras-Weber CC, et al. (1998) Study of the anti-hyperglycemic effect of plants used as antidiabetics. J Ethnopharmacol 61: 101-110.

85. Patel DK, Prasad SK, Kumar R, Hemalatha S (2012) An overview on antidiabetic medicinal plants having insulin mimetic property. Asian Pac J Trop Biomed 2: 320-330.

86. Mukherjee PK, Maiti K, Mukherjee K, Houghton PJ (2006) Leads from Indian medicinal plants with hypoglycemic potentials. J Ethnopharmacol 106: 1-28.

87. Bnouham M, Ziyyat A, Mekhfi H, Tahri A, Legssyer A (2006) Medicinal plants with potential antidiabetic activity - A review of ten years of herbal medicine research (1990-2000). International Journal of Diabetes and Metabolism 14: 1- 25 .

88. Patel DK, Kumar R, Laloo D, Hemalatha S (2012) Diabetes mellitus: an overview on its pharmacological aspects and reported medicinal plants having antidiabetic activity. Asian Pac J Trop Biomed 2: 411-420.

89. Kavishankar GB, Lakshmidevi N, Murthy SM, Prakash HS, Niranjana SR (2011) Diabetes and medicinal plants-A review. Journal of Pharmaceutical and Biomedical Sciences 2: 65-80.

90. Thirumalai T, Beverly CD, Sathiyaraj K, Senthilkumar B, David E (2012) Ethnobotanical Study of Anti-diabetic medicinal plants used by the local people 
Citation: Kayarohanam S, Kavimani S (2015) Current Trends of Plants Having Antidiabetic Activity: A Review. J Bioanal Biomed 7: 055-065. doi:10.4172/1948-593X.1000124

in Javadhu hills Tamilnadu, India. Asian Pacific Journal of Tropical Biomedicine 2: S910-S913.

91. Akah PA, Okoli CO, Nwafor SV (2002) Phytotherapy in the management of Diabetes mellitus. Journal of Natural Remedies 2: 1-10.

92. Raju Patil, Ravindra Patil, Bharati Ahirwar, Dheeraj Ahirwar (2011) Current status of Indian medicinal plants with antidiabetic potential: a review. Asian Pacific Journal of Tropical Biomedicine 2: S291-S298.

93. Srinivasan K, Ramarao P (2007) Animal models in type 2 diabetes research: an overview. Indian J Med Res 125: 451-472.

94. He CN, Wang CL, Guo SX, Yang JS, Xiao PG (2005) [Study on chemical constituents in herbs of Anoectochilus roxburghii II]. Zhongguo Zhong Yao Za Zhi 30: 761-763.
95. Jung M, Park M, Lee HC, Kang YH, Kang ES, et al. (2006) Antidiabetic agents from medicinal plants. Curr Med Chem 13: 1203-1218.

96. Oyedemi SO, Adewusi EA, Aiyegoro OA, Akinpelu DA (2011) Antidiabetic and haematological effect of aqueous extract of stem bark of Afzelia africana (Smith) on streptozotocin-induced diabetic Wistar rats. Asian Pac J Trop Biomed 1: 353-358.

97. Meliani N, Dib Mel A, Allali H, Tabti B (2011) Hypoglycaemic effect of Berberis vulgaris $\mathrm{L}$. in normal and streptozotocin-induced diabetic rats. Asian Pac J Trop Biomed 1: 468-471.

98. Patience O, Osadebe, Estella U, Odoh, Philip F, Uzor (2014) The search for new hypoglycemic agents from plants. African Journal of Pharmacy and Pharmacology 8: 292-303. 